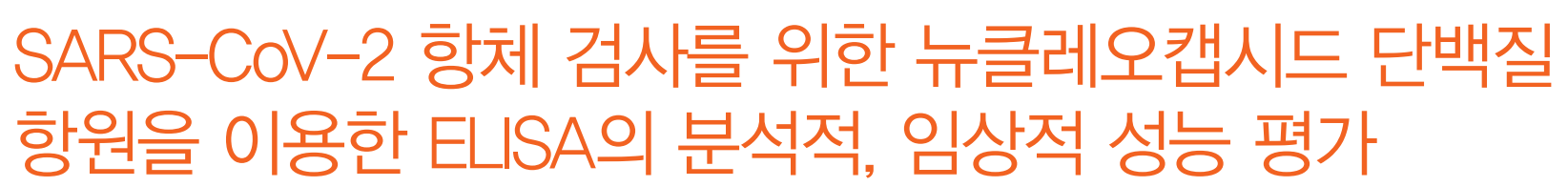

\title{
Evaluation of Clinical and Analytical Performance of a Nucleocapsid Protein Antigen- based ELISA for Detecting Antibodies against SARS-CoV-2
}

\author{
서인범 ${ }^{1} \cdot$ 김하나 ${ }^{2} \cdot$ 김채은 $^{3} \cdot$ 박종찬 $^{3} \cdot$ 김수현 $^{4} \cdot$ 민도식 ${ }^{4}$ \\ In Bum Suh, M.D. ${ }^{1}$, Hana Kim, Ph.D. ${ }^{2}$, Chae Eun Kim, MSc ${ }^{3}$, Jong-Chan Park, MSc ${ }^{3}$, Soohyun Kim, M.D. ${ }^{4}$, Do-CiC Mihn, M.D. ${ }^{4}$

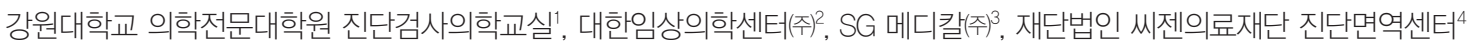

Department of Laboratory Medicine ${ }^{1}$, Kangwon National University College of Medicine, Chuncheon; Korea Clinical Medicine Center ${ }^{2}$, Chuncheon; SG Medical, Inc. ${ }^{3}$, Seoul; Department of Diagnostic Immunology4, Seegene Medical Foundation, Seoul, Korea
\end{abstract}

Background: As the coronavirus disease 2019 (COVID-19) pandemic evolves, the development of immunoassays that will help assess population exposure and potentially predict immunity has become a pressing priority.

Methods: We evaluated the performance of the R-FIND COVID-19 enzyme-linked immunosorbent assay (ELISA) (SG Medical. Inc., Korea) for semi-quantitative detection of IgG, IgM, and IgG/M/A total antibodies in serum samples, using the SARS-CoV-2 nucleocapsid protein as antigen. Serum samples from 87 patients with COVID-19 were tested for IgG and IgG/M/A. Samples from 19 patients were tested for IgM. Specimens from 160 patients without COVID-19 served as negative controls. Analytical performance was evaluated according to Ministry of Food and Drug Safety guidelines. Sensitivity and specificity were the primary measures of clinical performance.

Results: The analytical performance of the R-FIND COVID-19 ELISA met Ministry guidelines. Sensitivity and specificity were $94.25 \%$ and $98.13 \%$ for IgG, $95.40 \%$ and $98.13 \%$ for IgG/M/A, and $84.21 \%$ and $100 \%$ for IgM, respectively. IgM showed a $100 \%$ positive rate within 1 week of hospitalization, then decreased. IgG and IgG/M/A antibodies displayed $100 \%$ positivity after 2 weeks. IgG and IgG/M/A antibody titers steadily increased throughout patient hospitalization, but IgM titers gradually decreased.

Conclusions: The R-FIND COVID-19 ELISA detects IgG, IgM, and IgG/M/A and displays excellent analytical performance, sensitivity, and specificity. IgG titers increased steadily throughout hospitalization, but IgM titers peaked at one week post-hospitalization, and then steadily declined.

Key Words: COVID-19, SARS-CoV-2, Antibodies, ELISA, Serology

\section{서 론}

코로나바이러스감염증-19 (코로나19)는 새로 발견된 코로나바 이러스인 severe acute respiratory syndrome coronavirus 2 (SARS-

Corresponding author: Do-CiC Mihn, M.D., Ph.D.

(iD) https://orcid.org/0000-0002-5794-9714

Department of Diagnostic Immunology, Seegene Medical Foundation,

320 Cheonho-daero, Seondong-gu, Seoul 04805, Korea

Tel: +82-2-2218-9111, Fax: +82-2-2244-6508, E-mail: dsmin@mf.seegene.com

Received: January 8, 2021

Revision received: February 5, 2021

Accepted: February 9, 2021

This article is available from https://www.labmedonline.org (C) 2021, Laboratory Medicine Online

(a) This is an Open Access article distributed under the terms of the Creative Commons Attribution Non-Commercial License (https://creativecommons.org/licenses/by-nc/4.0/) which permits unrestricted non-commercial use, distribution, and reproduction in any medium, provided the original work is properly cited.
$\mathrm{CoV}-2)$ 로 인해 발생하는 감염질환으로 World Health Organization (WHO)에서 coronavirus disease-2019 (COVID-19)로 명명하였다 [1]. 코로나19 잠복기는 2일에서 14일로 알려져 있으며, 잠복기 이후 주요 임상증상으로는 발열, 기침, 호흡곤란, 오한 등이 나타난다[2]. 코로나19는 유전자 검사로 확진하며 실시간 역전사 중합효소연 쇄반응법(real-time reverse transcription polymerase chain reaction, rRT-PCR)이 사용된다. 우리나라에서는 WHO의 지침을 근거 로 유전자 검사 기준이 마련되었다[3]. 질병관리본부 감염병분석 센터 및 $\mathrm{WHO}$ 의 지침을 기준으로 작성된 코로나 19 검사실 진단 지침에 따르면, 필수 검체로 상기도 검체(비인두, 구인두 도말물) 및 하기도 검체(객담)를 채취하여 PCR 방법으로 SARS-CoV-2의 특 정 부위 유전자를 확인함으로써 감염을 확인한다. 이렇듯 현재 rRT-PCR이 확진 검사로 시행되고 있지만, 이 방법으로는 검체 내 바이러스 유전자의 존재에 민감하여 위양성이 나타나는 경우가 보고된 바 있고[4], 시간이 지난 후 바이러스 양이 적을 경우 위음 
성의 결과를 보이기도 하며, 검체 채취 과정에서의 바이러스 전파 의 위험성이 있으며 검체가 오염되기 쉽다는 단점이 있다[5]. 이와 같은 이유로, SARS-CoV-2에 대한 항체 검사의 필요성이 제기되었 다. $\mathrm{FDA}$ 에서는 항체 검사를 코로나 19 진단에 사용하지 말도록 권 고하고 있으나, 분자진단법과 병행하여 항체 검사를 시행하였을 때, 위음성의 경우 진단에 보완적인 역할을 할 뿐 아니라, 환자의 감염 후 회복 여부를 추적 관찰할 수 있는 장점이 있다. 또한 특정 국가나 특정 집단에서 SARS-CoV-2 항체 보유율을 조사함으로써 코로나19 감염률과 그에 따른 방역 효과의 평가 및 대책을 수립할 수 있을 것이며, 향후 백신 접종 후 면역력 획득을 파악하는데도 유용할 것이다. 최근에는 코로나19 회복 후 치료목적의 혈장 공여 자의 항체 보유의 선별 검사의 필요성과 해외 입국 시 항체 검사 결과를 요구하는 국가들도 있다.

SARS-CoV-2 항체를 검출하기 위한 대표적 항원으로 spike protein (SP)과 nucleocapsid protein (NP)을 사용한다. SP는 바이러스 가 세포 내로 들어가기 위해 세포와 결합하는 glycoprotein이며, $\mathrm{NP}$ 는 코로나바이러스의 가장 풍부한 단백질로, 게놈 RNA 전체를 감싸고 있으며 바이러스 입자 조립(assembly)과 방출(release)에 관여한다고 알려져 있다[6]. SARS-CoV-2의 SP가 NP보다 기존 바이 러스에 비해 변이가 더 많다고 알려져 있으므로 이론적으로 $\mathrm{SP}$ 를 항원으로 이용하는 것이 더 나을 것으로 보이나, 어떤 항원이 더 나은지는 연구마다 다르다. Suresh 등[7]에 따르면 기존 코로나바이 러스 감염 초기에 급격히 증가하는 $\mathrm{NP}$ 를 이용하여 항체를 검출하 는 것을 추천하였다. 이는 새로운 SARS-CoV-2에도 적용될 수 있을 것으로 생각하였다.

본 연구에서는 코로나 19 의 병원체인 SARS-CoV-2의 NP 특이적 항체를 검출하는 ELISA 시약을 개발 및 평가하였다. ELISA 시약은 총 세 종류로 혈청 검체 내의 SARS-CoV-2 NP 특이적 IgG, IgM, total 항체 (IgG, IgM, IgA 동시 검출)를 검출한다. 본 연구에서는 시약 의 분석적 성능을 평가하고, 민감도, 특이도, 양성예측도 및 음성 예측도를 제시하였다. 또한 코로나19 확진 판정 후 시간이 경과함 에 따라 변화하는 검체 내의 $\operatorname{IgG}, \operatorname{IgM}$ 및 total 항체 농도 추이를 확 인하고자 하였다.

\section{재료 및 방법}

\section{1. 대상}

본 연구에 사용된 검체는 강원대학교병원과 원주의료원에 내원 한 환자를 대상으로 하였다. 양성 검체는 rRT-PCR (PowerCheck ${ }^{\mathrm{TM}}$ 2019-nCoV Real-time PCR Kit, Kogenebiotech Co., Ltd., Seoul, Korea, 또는 Allplex ${ }^{\mathrm{TM}}$ 2019-nCoV Assay, Seegene Inc., Seoul, Korea) 로 코로나19 양성이 확인된 환자의 혈청으로, $\operatorname{IgG}$ 및 $\mathrm{IgG} / \mathrm{M} / \mathrm{A}$ 평
가에 사용된 양성 검체는 87 개이며 $\mathrm{IgM}$ 평가에 사용된 양성 검체 는 19개이다. 음성 검체는 rRT-PCR로 코로나19 음성으로 확인된 환자의 혈청 160 개를 사용하였다. 본 연구는 강원대학교병원 생명 의학연구윤리심의위원회의 승인을 받았다(KNUH-2020-05-015).

\section{2. 방법}

양성, 음성 혈청 검체를 R-FIND COVID-19 IgG ELISA (SG Medical, Inc., Seoul, Korea), R-FIND COVID-19 IgM ELISA (SG Medical, Inc., Seoul, Korea), R-FIND COVID-19 IgG/M/A ELISA (SG Medical, Inc., Seoul, Korea)를 이용하여 각각 SARS-CoV-2에 대한 $\mathrm{IgG}, \mathrm{IgM}, \mathrm{IgG} / \mathrm{M} / \mathrm{A}$ 를 측정하였다. 검체를 검체 희석액에 $1: 100$ 으 로 희석하여 $100 \mu \mathrm{L}$ 를 각 웰(well)에 첨가하여 45 분 동안 상온에서 반응시켰다. 양성대조(positive control)와 음성대조(negative control, NC)는 희석하지 않고 $100 \mu \mathrm{L}$ 를 각 웰에 첨가하였다. 음성대조 는 3중(triplicate)으로 웰에 첨가하였다. 반응 후 세척액(washing buffer) $300 \mu \mathrm{L}$ 로 3회 세척하였다. 웰에 남아 있는 세척액을 잘 털 어낸 후 IgG conjugate (또는 IgM conjugate, 또는 IgG/M/A conjugate)를 각 웰에 $100 \mu \mathrm{L}$ 첨가하여 30 분 동안 상온에서 반응시켰다. 세척액으로 3회 세척 후 $\mathrm{TMB}$ 기질(substrate) $100 \mu \mathrm{L}$ 첨가하여 15 분 동안 상온에서 반응시켰다. 반응중지액(stop reagent)을 $50 \mu \mathrm{L}$ 첨가하여 반응을 정지시키고 SpectraMax Plus384 (Molecular Devices LLC, California, USA)를 이용하여 $450 \mathrm{~nm}$ 에서의 흡광도(optical density, O.D.)를 측정하였다. 세 가지의 검사시약은 서로 다른 종류의 시약으로 구성되지만, 반응 시간과 온도 조건은 동일하였 다. 결과 판정은 제조사의 지침에 따라 흡광도 값을 이용하여 양성 과 음성 또는 무효로 하였다. 음성대조를 3 번 측정한 흡광도 값의 평균을 구해 제조사에서 제시한 숫자 $\mathrm{A}(\mathrm{IgG}$ 의 경우 $0.30, \mathrm{IgG} / \mathrm{M} /$ $\mathrm{A}$ 의 경우 $0.25, \mathrm{IgM}$ 의 경우 0.1 )를 더한 값에 1.1 을 곱한 값을 양성 판정 기준치, 0.9 를 곱한 값을 음성 판정 기준치로 하였다(검체 O.D. $\geq 1.1 \times(\mathrm{NC}$ 평균 $+\mathrm{A})$ 일 때 양성, 검체 O.D. $\leq 0.9 \times(\mathrm{NC}$ 평균 $+\mathrm{A})$ 일 때 음성). 양성과 음성의 판정 기준치 사이로 측정되면 재검 하였으며, 재검 후에도 두 판정 기준치 사이 값이 나올 경우 결과 는 무효로 하였다.

\section{3. 분석적 성능}

\section{1) 최소검출한계(Limit of detection, LoD)}

최소검출한계는 일반적으로 $95 \%$ 확률로 양성으로 구분되는 측 정 결과를 보이는 측정량 농도로 계산되는데, R-FIND COVID-19 ELISA 시약은 정성검사이기 때문에 검체의 농도를 표현하지 못하 므로, $450 \mathrm{~nm}$ 에서의 흡광도 값으로 최소검출한계를 제시하였다 [8]. 양성으로 확인된 혈청 검체를 희석하여 저농도 양성 검체를 확 보하였고, 5 개의 저농도 양성 검체를 3 일간 4 번 반복 측정하여 총 
60 회의 결과 중 $95 \%$ 이상이 양성으로 검출되는 흡광도 값을 시약 의 최소검출한계로 제시하였다.

\section{2) 정밀도(Precision)}

CLSI (Clinical and Laboratory Standard Institute) 가이드라인에 따라 3가지 농도의 검체를 이용해 실험을 하였으며, 결과를 변이계 수(coefficient of variation, $\mathrm{CV}$ )로 제시하였다. 정밀도 중 반복성 (repeatability)은 한 명의 검사자가 10 일 동안 하루 2 회, 두 번 반복 검사한 결과로 검사 내, 검사 간, 날짜 간, 검사실 내 정밀도이고, 재 현성(reproducibility)은 두 명의 검사자가 5 일 동안 하루 2 회, 두 번 반복 검사한 장소 간, 날짜 간, 검사자 간, 로트 간 정밀도이다[9-11].

\section{3) 교차반응(Cross-reactivity)}

호흡기 질환 관련 질병에 양성으로 확인된 혈청 검체 Influenza A IgA 양성 4건, Influenza B IgA 3건, 호흡기세포융합바이러스(respiratory syncytial virus, RSV) IgM 5건, RSV IgG 2건, SARS-CoV $\operatorname{IgG}$ 9건을 세 번 반복 검사하였다.

\section{4) 간섭반응(Interference)}

간섭반응은 내인성 물질 4종(hemoglobin, albumin, triglycerides, unconjugated bilirubin), 외인성 물질 2종(erythromycin, tetracycline)을 3 가지 농도의 혈청 검체에 첨가하여 검사하였다. 3 가 지 농도는 R-FIND COVID-19 ELISA 각 시약의 시험 결과를 기준 으로 하였으며, $450 \mathrm{~nm}$ 에서 O.D. 2.0 이상은 SARS-CoV-2 항체 고 농도, O.D. 0.5-1.5 값은 중간농도, O.D. 0.3 미만은 저농도 검체로 정의하였다. 혈색소, 알부민, erythromycin, tetracycline은 $0.9 \%$ $\mathrm{NaCl}$ 용액에 20배 진하게 준비하여 검사 시 검체에 $1 / 20$ (부피비) 로 첨가하였고, 빌리루빈은 $0.1 \mathrm{~N} \mathrm{NaOH}$ 용액에 20 배 진하게 준비 하여 마찬가지로 검사 시 검체에 $1 / 20$ 로 첨가하였다. 중성지방은 상온에서 고체 상태이기 때문에 $50^{\circ} \mathrm{C}$ 이상에서 액체 상태로 녹여 희석하지 않고 검체에 $1 / 20$ 로 첨가하였다. 간섭물질이 첨가되지 않 은 검체는 $1 / 20$ 만큼 $0.9 \% \mathrm{NaCl}$ 용액을 첨가하여 실험군과의 농도 를 동일하게 해 주었다. 간섭물질을 첨가한 검체의 흡광도가 대조 군과 $15 \%$ 미만의 차이를 보이면 간섭반응이 없다고 간주하였다 $[12,13]$.

\section{4. 임상적 성능}

양성 검체는 총 87개로, rRT-PCR로 SARS-CoV-2 양성 확인된 환 자에서 채취한 혈청이며, 총 160 개의 음성 검체는 rRT-PCR로 음성 확인된 비감염자에게서 채취한 혈청이다. $\mathrm{IgG}$ ELISA와 $\mathrm{IgG} / \mathrm{M} / \mathrm{A}$ ELISA로는 동일한 검체를 평가하였고, 환자군의 평균 연령은 54.2 \pm 8.0 세(범위 46.2-62.2), 남녀 비율은 0.79이었다. IgM ELISA로 검
사한 양성 검체는 19 개이며, 환자군의 평균 연령은 $56.7 \pm 26.4$ 세 (범위 30.3-83.1), 남녀 비율은 0.5 이었다. 양성 혈청은 코로나 19 확 진 된 환자의 입원 기간 동안 간헐적으로 채취되어 시간이 경과함 에 따라 항체의 역가 변화를 관찰하였다. 환자의 입원 기간은 최대 58일이었다. 양성 및 음성 검체를 검사한 결과로 R-FIND COVID-19 ELISA 시약의 민감도와 특이도, 그리고 그에 대한 $95 \%$ 신뢰 구간 (confidence interval, $\mathrm{CI}$ )을 구하였다.

\section{5. 통계방법}

정밀도의 계산은 CLSI EP05-A2와 EP15-A2의 통계적 계산식을 참고하였다 [10, 11]. 양성과 음성 검체의 흡광도의 차이는 Med-Calc version 19.5.2 (Med-Calc Software Ltd., Ostend, Belgium) 프로그 램을 이용하여 상자 수염 그림(box-and-whisker plot)으로 도식화 하였다. R-FIND COVID-19 ELISA 시약의 임상적 민감도, 특이도, 양성예측도 및 음성예측도는 rRT-PCR 검사법의 양성, 음성 결과를 바탕으로 계산되었다. 그 외 모든 통계처리는 Microsoft Excel (Microsoft Corporation, WA, USA)을 이용하였다.

\section{결 과}

\section{1. 분석적 성능 평가}

분석적 성능 결과는 Table 1에 요약하였다. R-FIND COVID-19 $\mathrm{IgG}, \mathrm{IgG} / \mathrm{M} / \mathrm{A}, \mathrm{IgM} \mathrm{ELISA}$ 의 최소 검출 한계 흡광도는 각각 0.502 ,

Table 1. Analytical performance of the R-FIND COVID-19 lgG, IgG/M/ A and IgM ELISA

\begin{tabular}{lccc}
\hline & $\begin{array}{c}\text { R-FIND COVID-19 } \\
\text { lgG-FIND COVID-19 }\end{array}$ & $\begin{array}{c}\text { R-FIND COVID-19 } \\
\text { lgG/M/A }\end{array}$ & IgM \\
\hline Limit of detection & $<0.502$ & $<0.481$ & $<0.198$ \\
Precision (CV) & & & \\
- Repeatability & & & \\
Within-run & $10.24 \%$ & $3.81 \%$ & $6.86 \%$ \\
Between-runs & $3.99 \%$ & $2.00 \%$ & $2.22 \%$ \\
Between-days & $0.96 \%$ & $5.64 \%$ & $3.33 \%$ \\
Within-laboratory & $8.83 \%$ & $6.80 \%$ & $7.08 \%$ \\
- Reproducibility & & & \\
Between-sites & $11.22 \%$ & $7.89 \%$ & $7.83 \%$ \\
Between-days & $11.21 \%$ & $7.91 \%$ & $7.81 \%$ \\
Between-operators & $11.78 \%$ & $7.90 \%$ & $7.81 \%$ \\
Between-lots & $11.20 \%$ & $7.84 \%$ & $7.74 \%$ \\
Cross-reactivity & No cross-reactivity to Influenza A IgA, Influenza B IgA, \\
& RSV IgM, RSV IgG, SARS-CoV IgG positive serum \\
Interference & Recovery rate: & Recovery rate: & Recovery rate: \\
(control: 100\%) & $89.71-107.90 \%$ & $95.27-106.25 \%$ & $89.71-107.90 \%$ \\
\hline
\end{tabular}

Abbreviations: COVID-19, coronavirus disease 2019; CV, coefficient of variation; RSV, respiratory syncytial virus; SARS-CoV, severe acute respiratory syndrome coronavirus. 
$0.481,0.198$ 이며, 정밀도는 모든 시약에서 CV $15 \%$ 미만이었다. Influenza A IgA, Influenza B IgA, RSV IgM, RSV IgG, SARS-CoV IgG 양성 혈청으로 세 제품으로 검사를 했으며, 모두 음성으로 간섭반 응은 없었다. 간섭반응의 경우, CLSI 가이드라인[12, 13]에 따라 고 농도의 간섭 물질을 첨가했을 때 대조군과 실험군의 결과가 $15 \%$ 미만의 차이를 보여 간섭반응이 없음을 확인하였다.

Table 2. Clinical performance of the R-FIND COVID-19 IgG, IgG/M/A and IgM ELISA

\begin{tabular}{lccc}
\hline & $\begin{array}{c}\text { R-FIND COVID-19 } \\
\text { lgG }\end{array}$ & $\begin{array}{c}\text { R-FIND COVID-19 lgG/ } \\
\text { M/A }\end{array}$ & $\begin{array}{c}\text { R-FIND COVID-19 } \\
\text { IgM }\end{array}$ \\
\hline Sensitivity & $94.25 \%(82 / 87)$ & $95.40 \%(83 / 87)$ & $84.21 \%(16 / 19)$ \\
& $95 \% \mathrm{Cl}(87.10-98.11)$ & $95 \% \mathrm{Cl}(88.64-98.73)$ & $95 \% \mathrm{Cl}(73.31-99.85)$ \\
Specificity & $98.13 \%(157 / 160)$ & $98.13 \%(157 / 160)$ & $100.00 \%(160 / 160)$ \\
& $95 \% \mathrm{Cl}(94.62-99.61)$ & $95 \% \mathrm{Cl}(94.62-99.61)$ & $95 \% \mathrm{Cl}(97.72-100)$ \\
PPV & $96.47 \%$ & $96.51 \%$ & $100 \%$ \\
& $95 \% \mathrm{Cl}(89.90-98.82)$ & $95 \% \mathrm{Cl}(90.01-98.84)$ & $95 \% \mathrm{Cl}(95.01-100)$ \\
NPV & $96.91 \%$ & $97.52 \%$ & $98.16 \%$ \\
& $95 \% \mathrm{Cl}(93.06-98.66)$ & $95 \% \mathrm{Cl}(93.78-99.03)$ & $95 \% \mathrm{Cl}(95.98-99.91)$ \\
\hline
\end{tabular}

Abbreviations: COVID-19, coronavirus disease 2019; PPV, positive predictive value; NPV, negative predictive value.

\section{2. 임상적 성능 평가}

시약의 임상적 민감도와 특이도는 R-FIND COVID-19 IgG ELISA 에서 $94.25 \%$ 와 $98.13 \%, \mathrm{IgG} / \mathrm{M} / \mathrm{A}$ 에서 $95.40 \%$ 와 $98.13 \%, \mathrm{IgM}$ 에서 $84.21 \%$ 와 $100 \%$ 를 보였다(Table 2). 양성예측도와 음성예측도는 모 든 시약에서 $95 \%$ 이상의 결과를 보였다. Fig. 1은 rRT-PCR로 양성 확인된 환자의 혈청과 음성 확인된 비감염자의 혈청을 검사한 흡 광도 값을 나타낸 상자 수염 그림(box-and-whisker plot)이며, 양성 과 음성에서 상자가 중복되지 않고 구별되는 결과가 나타났다.

Table 3. Positive rates of $\lg G, \lg G / M / A$, and $\lg M$ detection versus week post hospitalization

\begin{tabular}{lccc}
\hline \multirow{2}{*}{ Week } & \multicolumn{3}{c}{ Positive rate (number of serum samples with positive results) } \\
\cline { 2 - 4 } & $\begin{array}{c}\text { R-FIND COVID-19 } \\
\text { IgG }\end{array}$ & $\begin{array}{c}\text { R-FIND COVID-19 } \\
\text { IgG/M/A }\end{array}$ & $\begin{array}{c}\text { R-FIND COVID-19 } \\
\text { IgM }\end{array}$ \\
\hline$<1$ & $90.63 \%(29 / 32)$ & $93.75 \%(30 / 32)$ & $100 \%(7 / 7)$ \\
$1-2$ & $93.33 \%(28 / 30)$ & $93.33 \%(28 / 30)$ & $80.00 \%(4 / 5)$ \\
$>2$ & $100 \%(25 / 25)$ & $100 \%(25 / 25)$ & $71.43 \%(5 / 7)$ \\
\hline
\end{tabular}

Abbreviation: COVID-19, coronavirus disease-2019.

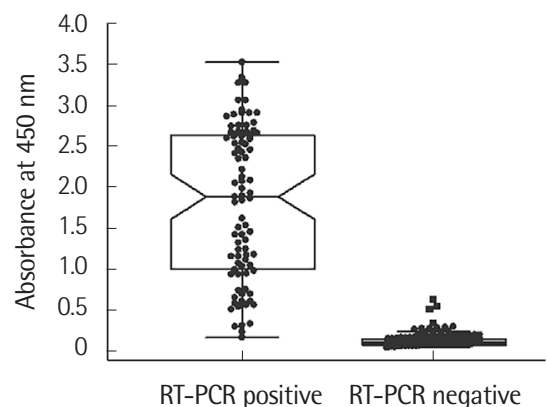

R-FIND COVID-19 IgG

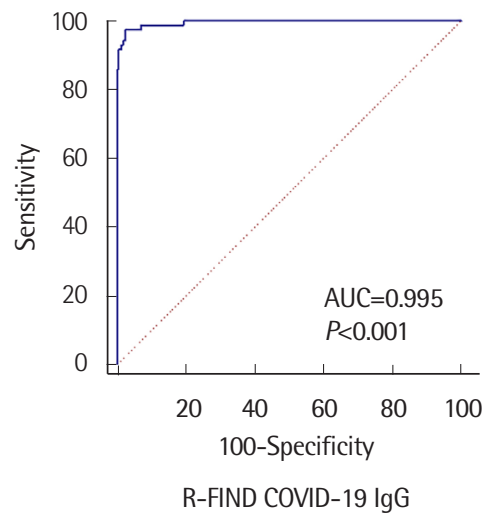

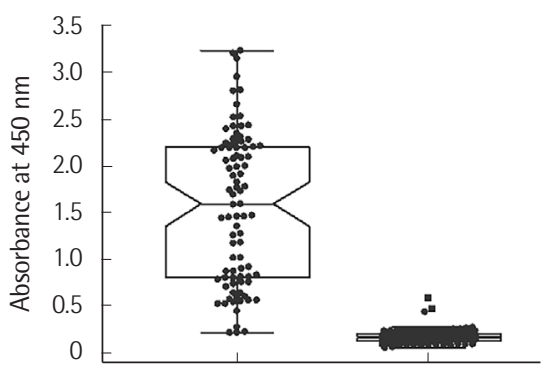

RT-PCR positive RT-PCR negative R-FIND COVID-19 lgG/M/A

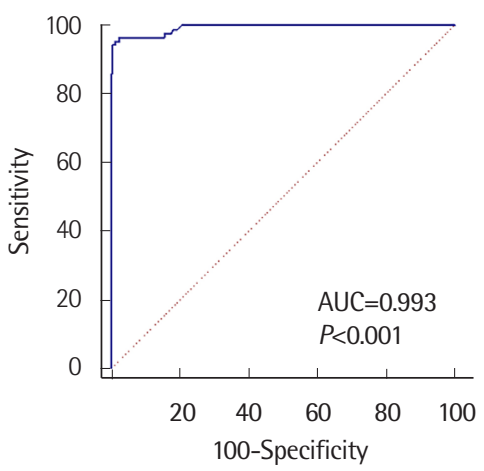

R-FIND COVID-19 lgG/M/A

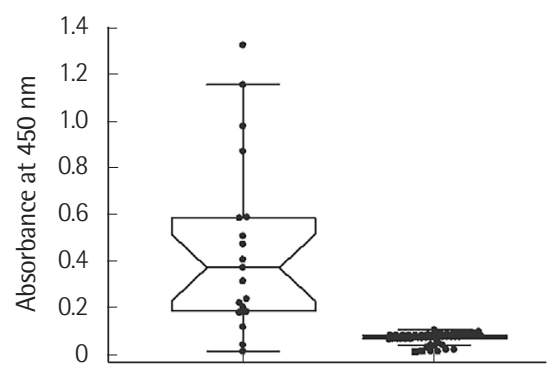

RT-PCR positive RT-PCR negative R-FIND COVID-19 IgM

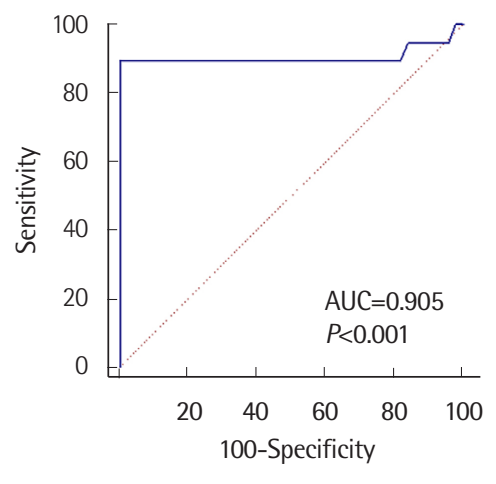

R-FIND COVID-19 IgM

Fig. 1. Results of SARS-CoV-2 antibody detection. A) Levels of antibodies against SARS-CoV-2 in serum from healthy individuals and patients confirmed positive by rRT-PCR. Box-and-whisker plot shows minimum value, first quartile, median, third quartile, and maximum value for each data set. B) ROC analysis of the R-FIND COVID-19 ELISA series.

Abbreviations: SARS-CoV-2, severe acute respiratory syndrome coronavirus 2; rRT-PCR, real-time reverse transcription PCR; COVID-19, coronavirus disease 2019. 


\section{3. 항체가의 변화}

R-FIND COVID-19 ELISA는 정성 시약이지만 결과가 흡광도로 수치화되기 때문에 항체의 농도와 항체가의 변화를 반정량적으로 파악할 수 있다. 항체가의 변화를 파악하기 위해 간헐적으로 채취 된 입원한 환자의 혈청을 검사하여, 시간이 경과함에 따라 항체 농 도 변화를 관찰하였다. 기간별 양성률은 IgG ELISA에서 1주 이내 $90.63 \%, 1-2$ 주에서 $93.33 \%$, 2주 이후 $100 \%$ 였다. IgG/M/A ELISA에 서는 1주 이내 $93.75 \%, 1-2$ 주에서 $93.33 \%$, 2주 이후 $100 \%$ 였으며, IgM ELISA에서 1주 이내 100\%, 1-2주에서 80\%, 2주 이후 $71.43 \%$ 였 다(Table 3, Fig. 2). IgG 역가는 확진 판정 후 지속적으로 증가하고 2 주 이후에도 감소하지 않는 것으로 나타났다. 마찬가지로 $\mathrm{IgG} / \mathrm{M} /$ $\mathrm{A}$ 의 역가도 전체 환자군을 대상으로 검사하였을 때 항체가가 지속 적으로 증가하였다. $\mathrm{IgM}$ 역가는 시간 경과에 따라 감소하였다.

입원 환자 7 명의 연속 채혈을 통한 항체가의 변화는 입원 후 $\operatorname{IgG}$

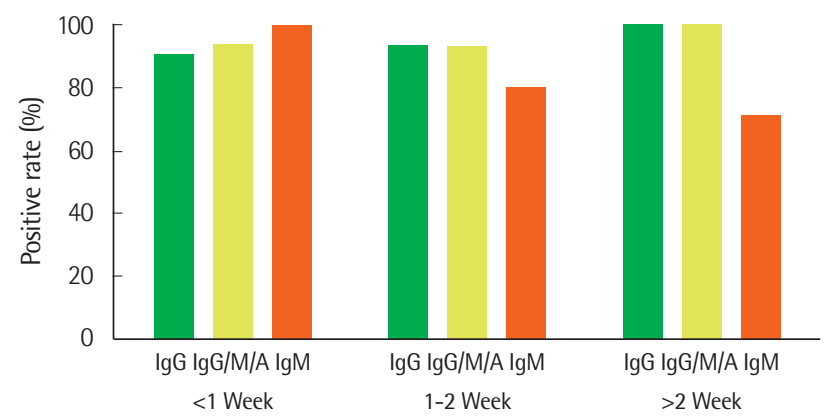

Fig. 2. Comparison of SARS-CoV-2 IgG, $\lg G / M / A$, and $\lg M$ positive rates by week post-hospitalization.

Abbreviation: SARS-CoV-2, severe acute respiratory syndrome coronavirus 2.
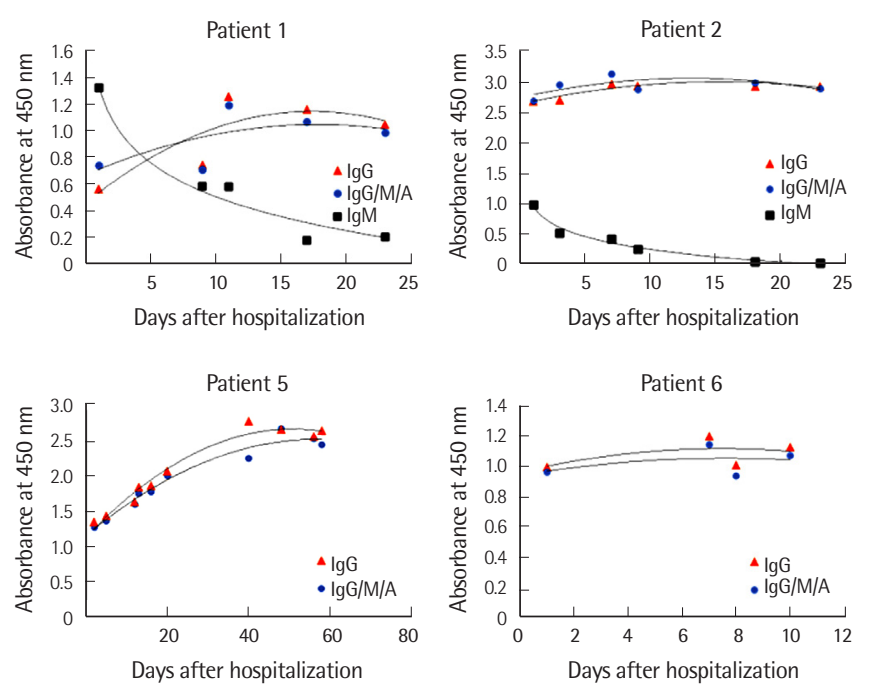

와 $\mathrm{IgG} / \mathrm{M} / \mathrm{A}$ 항체가가 지속적으로 증가하였다(Fig. 3). 그 중 3명의 환자에서 IgM 역가를 동시에 측정할 수 있었으며, 세 명 모두에서 항체가가 감소하는 것을 확인하였다.

\section{고 찰}

SARS-CoV-2 항체를 검출하기 위하여 SP 또는 NP 항원을 단독 으로 이용하거나, 혼합하여 사용한다. 시약 성능은 항원 종류 및 제조사에 따라 차이를 보인다. 본 연구에서 두 항원을 각각 이용하 여 실험한 결과, $\mathrm{SP}$ 의 경우 기존 코로나바이러스와 교차 반응 및 위음성의 결과를 보인 반면 NP에서 좋은 결과를 얻게 되어 NP를 항원으로 이용하게 되었다.

본 연구에서 개발된 세 가지 시약의 임상적 민감도와 특이도는 타 연구에서 보고된 ELISA 시약보다 높았다[14, 15]. 타 연구는 코 로나19 초기의 문헌으로 항원의 종류나 제조에 따른 시약의 민감 도나 안정성에서 문제가 있었을 것으로 보이며, 연구 대상의 수가 적고 코로나 19 의 확진에 문제가 있었을 가능성도 있을 것으로 생 각된다.

rRT-PCR 양성이나 항체에서 음성인 경우는 증상 발현 시점을 정확히 알 수는 없으나 입원 후 초기에 채혈한 검체에서 주로 나왔 으며, rRT-PCR의 역치 사이클(threshold cycle, Ct) 값과는 연관성 이 없었다. 이를 볼 때, 위음성의 결과는 SARS-CoV-2 감염 후 체내 면역이 형성되기 전의 시기에 채혈 되었을 가능성이 높을 것으로 생각된다. 또한 항체를 검출하기 위한 항원의 안정성 또는 민감도 문제도 배제할 수 없다. 한편 IgM ELISA의 경우, 특이도는 $100 \%$ 로 높지만 민감도가 $84.21 \%$ 로 낮았다. 이는 대상자 수가 적어 통계적
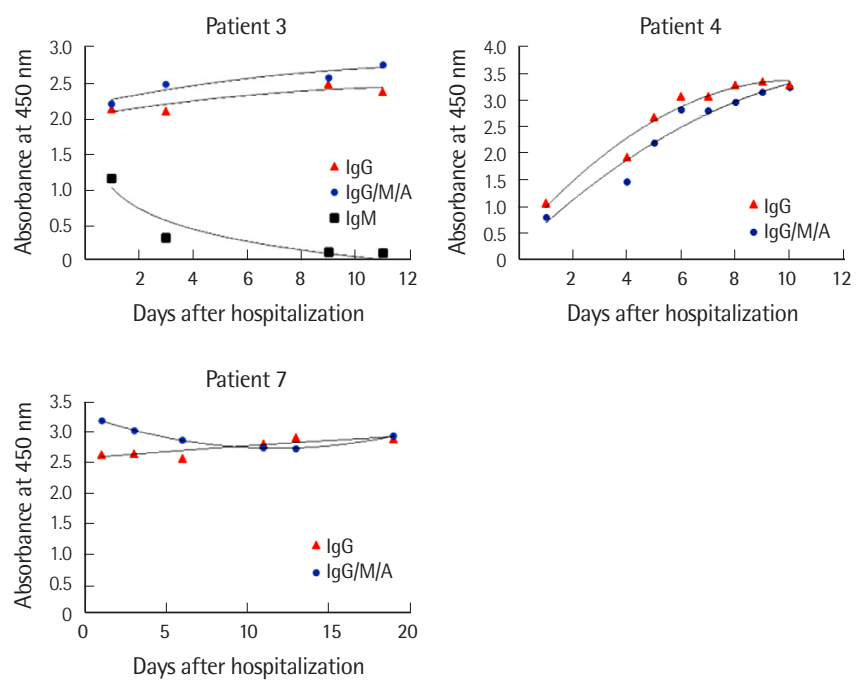

Fig. 3. Fitted curves of anti-SARS-CoV-2 IgG, IgG/M/A, and IgM production kinetics (relative to days of hospitalization) by ELISA. Seven patients' results are presented.

Abbreviation: SARS-CoV-2, severe acute respiratory syndrome coronavirus 2. 
유의성이 있다고 보기는 어려우나, 시간이 지날수록 $\operatorname{IgM}$ 역가가 감소하는 경향과 연관이 있어 보인다. $\mathrm{IgG} / \mathrm{M} / \mathrm{A}$ 의 1-2주에서의 양 성률 감소는 IgM의 영향이 있을 것으로 여겨진다.

$\mathrm{IgG} / \mathrm{M} / \mathrm{A}$ 의 역가가 2 주 이후에 $100 \%$ 로 나타난 것은 $\operatorname{IgG}$ 의 영향 이 큰 것으로 보인다. IgM 역가의 감소는 여러 문헌에서 보고된 바 있다. Tré-Hardy 등[16]에 따르면, IgM 농도는 3주까지 증가하다가 그 이후 감소하였다. 그러나 본 연구에서 사용된 혈청 검체를 채취 한 날짜의 기준이 감염 후가 아닌 확진 후이기 때문에 $\mathrm{IgM}$ 의 감소 가 더 이른 날짜에 나타난 것처럼 보일 수 있다. 일반적으로 혈청 내의 병원체 특이적인 $\mathrm{IgM}$ 역가는 감염 후 증가하였다가 시간이 경과함에 따라 감소하는데, 코로나19에서도 IgM의 역가가 감염 후 일정 시간이 지나면 감소하는 것으로 보인다. 따라서 본 연구에서 의 IgM 양성률의 감소도 이와 관련된 것으로 보인다. Liu 등[17]에 따르면 코로나 19 환자 중 회복되는 환자에서 SARS-CoV-2에 대한 $\operatorname{IgM}$ 역가가 고위험환자에 비해 유의하게 감소한다는 연구 결과가 있다. 본 연구는 질환의 중증을 분류하지 않아 임상적 의의를 판 단하기 어려웠다.

$\mathrm{IgG}$ 의 경우 시간이 경과함에 따라 항체가가 감소하지 않았다. MERS-CoV 유행 당시 WHO는 급성기 및 회복기 혈청에서 혈청 전 환 또는 IgG 역가의 4 배 이상 증가로 감염 진단을 권장하였는데, Long 등[18]의 연구에 의하면 SARS-CoV-2에 대해서도 동일한 기준 이 적용 가능함을 확인한 바 있다. 그러므로 본 연구에서 얻은 $\operatorname{IgG}$ 와 $\mathrm{IgG} / \mathrm{M} / \mathrm{A}$ 의 연관성 있는 결과도 $\mathrm{IgG}$ 의 상당한 증가 때문인 것 으로 보인다. $\mathrm{IgG}, \mathrm{IgM}$ 의 개별 결과들과 $\mathrm{IgG} / \mathrm{M} / \mathrm{A}$ 의 결과가 부합되 는 것을 확인할 수 있었다. 경제적인 면을 고려한다면 $\mathrm{IgG} / \mathrm{M} / \mathrm{A}$ 를 선별검사로 이용하고, 양성인 경우 $\operatorname{IgG}, \mathrm{IgM}$ 개별 검사를 시행하 면 좋을 것으로 판단된다.

코로나19의 면역진단 검사법은 측면 유동 면역검사법(rapid lateral flow immunoassay, LFIA), 화학발광면역측정법(chemiluminescence immunoassay, CLIA), 그리고 효소면역측정법(enzymelinked immunosorbent assay, ELISA) 등으로 수행되고, 여러 체외 진단기기 업체에서 개발한 제품들은 혈청이나 혈장에서 SARS$\mathrm{CoV}-2$ 특이적 항체를 검출한다[19]. 상용화된 면역진단 제품들은 $\mathrm{IgG}$ 와 $\mathrm{IgM}$ 을 각각 검출하거나, $\mathrm{IgG} / \mathrm{IgM}$ 동시 검출, $\mathrm{IgG} / \mathrm{M} / \mathrm{A}$ 동시 검출하는 제품 등으로 나뉜다. 또한, 일반적으로 ELISA법은 LFIA 법보다 시간이 더 걸리지만 민감도와 특이도가 높고, 한 번에 여러 검체를 동시에 검사할 수 있다는 장점이 있다. 그러나 바이러스의 존재 유무를 직접적으로 검사하는 방법이 아니기 때문에 감염증 을 직접 진단할 수 없는 한계점이 있다. 그럼에도 불구하고 항체 검 사는 여러 문헌에서 $\mathrm{PCR}$ 검사의 보조적 역할로 실시할 필요성이 보고되었다[20].

본 연구에서 평가한 환자 중 Patient 5 (Fig. 3)는 입원 후 27-40일
사이에 rRT-PCR 검사 결과가 음성으로 확인되었으나 이후 재검사 한 결과가 다시 rRT-PCR 양성으로 확인되어 58일 이후까지 장기 입원한 환자이다. 비록 이 환자를 대상으로 $\operatorname{IgM}$ 검사를 시행하지 않아 아쉽지만, IgM 검사를 시행하여 지속적으로 증가하는 양상 을 확인하였다면 환자의 상태를 파악하는 데 도움이 되었을 것으 로 기대된다. 향후 항체 검사를 rRT-PCR 검사와 병행한다면 환자 의 치료 모니터링에 도움이 될 수 있을 것으로 생각된다.

본 연구의 한계점은 먼저 $\operatorname{IgM}$ 양성 검체가 너무 적어서 $\operatorname{IgM}$ 을 정확하게 평가하기에는 무리가 있어 보인다. 또한 연구 당시 식약 처에 정식 등록되어 있는 제품이 없어 비교평가 할 수가 없었다. 항 체 역가의 연구에서도 대상자 수가 적고, 입원 후 시간을 기준으로 하여 감염 시작의 정확한 시점을 알 수 없었고, 검체를 채취할 수 있는 기간도 짧아서 정확한 항체 역가의 변화를 일반화할 수 없는 아쉬운 점이 있었다. 하지만 국내에서 개발한 제품으로서 SARS$\mathrm{CoV}-2$ 항체를 검출하는 데 높은 성능을 보였고, 항체 역가의 변화 를 추적할 수 있었다는 데 의미가 있다고 본다. 더 많은 환자를 대 상으로 재평가가 필요해 보이며, 특히 항체의 지속 여부에 대해서 는 더 오랜 기간을 둔 연구가 필요할 것으로 보인다. 또한 항체 양 성 시 중화항체와의 연관성에 대한 연구도 필요해 보인다.

결론적으로 본 연구에서 평가한 R-FIND COVID-19 ELISA 시약 은 효소면역측정법을 이용하여 코로나 19 항체를 검출하는 시약으 로 높은 분석적 성능과 함께 높은 민감도와 특이도를 보였다. 코로 나 19 의 병원체인 SARS-CoV-2의 NP에 특이적인 $\mathrm{IgG} / \mathrm{M} / \mathrm{A}$ 를 동시 에 검출하여 선별 검사에 이용하고, 양성 시 IgG, IgM을 단독으로 검출하는 시약을 통해 환자의 상태를 구분하는데 도움을 줄 수 있 을 것이다. 또한 ELISA 검사로 다량의 검체를 동시에 검사할 수 있 는 장점이 있다. 본 연구를 통해 SARS-CoV-2 항체는 다른 종류의 코로나 바이러스와 유사하게 IgM은 시간이 경과할수록 감소하며, $\operatorname{IgG}$ 는 지속적으로 유지되었다.

\section{요 약}

배경: 코로나바이러스감염증-19 (코로나19)의 팬데믹이 발생하였 고, 면역검사를 통한 SARS-CoV-2 (severe acute respiratory syndrome coronavirus 2)에 대한 항체 검사의 필요성이 대두되었다.

방법: SARS-CoV-2의 특이 IgG, IgM, IgG/M/A total 항체를 각각 검 출하는 R-FIND COVID-19 ELISA IgG, IgM, IgG/M/A (SG Medical, Inc., Korea) 3 가지 종류의 시약을 개발하여 이를 평가하였다. 코로 나 19 양성이 확인된 환자 87 명을 대상으로 $\operatorname{IgG}$ 및 $\mathrm{IgG} / \mathrm{M} / \mathrm{A}$ 를 평가 하였고, IgM 평가에는 양성 환자 19명을 대상으로 하였다. 음성대 조군으로 코로나 19 음성 160 명을 대상으로 하였다. 분석적 성능에 대해서는 식품의약품안전처의 체외진단 의료기기 임상적 성능시 
험 가이드라인에 따라 평가하였으며, 임상적 성능으로 민감도와 특이도를 평가하였다.

결과: R-FIND COVID-19 ELISA 시약의 분석적 성능은 가이드라인 을 만족시켰다. 민감도와 특이도는 각각 $\mathrm{IgG}$ 에서 $94.25 \%$ 와 $98.13 \%, \mathrm{IgG} / \mathrm{M} / \mathrm{A}$ 에서 $95.40 \%$ 와 $98.13 \%, \operatorname{IgM}$ 에서 $84.21 \%$ 와 $100 \%$ 로 나타났다. 환자 입원 후 $\mathrm{IgM}$ 은 1주 이내 $100 \%$ 양성률을 보였으 며, 이후에는 감소하였다. 반면 $\mathrm{IgG}$ 와 $\mathrm{IgG} / \mathrm{M} / \mathrm{A}$ 항체는 2 주 후에 $100 \%$ 를 보였다. 입원 환자 연속 채혈을 통한 항체가의 변화는 입 원 후 $\operatorname{IgG}$ 와 $\operatorname{IgG} / \mathrm{M} / \mathrm{A}$ 항체가는 지속적으로 증가하였으나, $\operatorname{IgM}$ 역 가는 점차 감소하였다.

결론: R-FIND COVID-19 ELISA IgG, IgM, IgG/M/A 세 종류의 시 약은 국내에서 개발된 제품들로 분석적 성능, 민감도와 특이도가 우수하였다. $\operatorname{IgG}$ 의 항체가는 양성으로 유지되나 $\operatorname{IgM}$ 의 항체가는 입원 후 지속적으로 감소하였다.

\section{이해관계}

김채은, 박종찬은 ELISA 개발자들이며, 그 외 저자들은 본 연구와 관련하여 어떠한 이해관계도 없음을 밝힙니다.

\section{REFERENCES}

1. Gorbalenya AE, Baker SC, Baric RS, de Groot RJ, Drosten C, Gulyaeva AA, et al. The species severe acute respiratory syndrome-related coronavirus: classifying 2019-nCoV and naming it SARS-CoV-2. Nat Microbiol 2020;5:536-44.

2. Korea Centers of Disease Control and Prevention. Guidelines in response to coronavirus disease 2019. 7-3rd ed (for local government). http://www.gidcc.or.kr/wp-content/uploads/2020/02/0315-\%EC\%BD \%94\%EB\%A1\%9C\%EB\%82\%98\%EB\%B0\%94\%EC\%9D\%B4\%EB\%9F\% AC\%EC\%8A\%A4\%EA\%B0\%90\%EC\%97\%BC\%EC\%A6\%9D-19-\%EB\%8 C\%80\%EC\%9D\%91\%EC\%A7\%80\%EC\%B9\%A8\%EC\%A7\%80\%EC\%9E \%90\%EC\%B2\%B4\%EC\%9A\%A97-3\%ED\%8C\%90.hwp (Updated on Mar 2020).

3. Kim HS, Hong KH, Sung HS, Lee HM, Kim JS. Laboratory tests for diagnosis of coronavirus disease 2019 (COVID-19). JoHTA 2020;8:14-9.

4. Tahamtan A and Ardebili A. Real-time RT-PCR in COVID-19 detection: issues affecting the results. Expert Rev Mol Diagn 2020;20:453-4.

5. Guo L, Ren L, Yang S, Xiao M, Chang D, Yang F, et al. Profiling early humoral response to diagnose novel coronavirus disease (COVID-19). Clin Infect Dis 2020;71:778-85.

6. Gralinski LE and Menachery VD. Return of the coronavirus: 2019-nCoV.
Viruses 2020;12:135.

7. Suresh MR, Bhatnagar PK, Das D. Molecular targets for diagnostics and therapeutics of severe acute respiratory syndrome (SARS-CoV). J Pharm Pharm Sci 2008;11:1s-13s

8. Clinical and Laboratory Standards Institute. Evaluation of detection capability for clinical laboratory measurement procedures; Approved guideline-Second edition. CLSI document EP17-A2. Wayne, PA: Clinical and Laboratory Standards Institute, 2012.

9. Clinical and Laboratory Standards Institute. Evaluation of precision of quantitative measurement procedures; Approved guideline-Third edition. CLSI document EP05-A3. Wayne, PA: Clinical and Laboratory Standards Institute, 2014.

10. Clinical and Laboratory Standards Institute. Evaluation of precision performance of quantitative measurement methods; Approved guideline-Second edition. CLSI document EP05-A2. Wayne, PA: Clinical and Laboratory Standards Institute, 2004.

11. Clinical and Laboratory Standards Institute. User verification of performance for precision and trueness; Approved guideline-Second edition. CLSI document EP15-A2. Wayne, PA: Clinical and Laboratory Standards Institute, 2006.

12. Clinical and Laboratory Standards Institute. Interference testing in clinical chemistry, 3rd Edition. CLSI guideline EP07. Wayne, PA: Clinical and Laboratory Standards Institute, 2018.

13. U.S. Department of Health and Human Services Food and Drug Administrations. Bioanalytical method validation; Guidance for industry. Docket No. FDA-2013-D-1020. Silver Spring, MD: Center for Drug Evaluation and Research, Food and Drug Administrations, 2013. https:// www.fda.gov/files/drugs/published/Bioanalytical-Method-ValidationGuidance-for-Industry.pdf (Updated on May 2018).

14. Krüttgen A, Cornelissen CG, Dreher M, Hornef M, Imöhl M, Kleines M. Comparison of four new commercial serologic assays for determination of SARS-CoV-2 IgG. J Clin Virol 2020;128:104394.

15. Seegmiller JC, Kokaisel EL, Story SJ, Zaun CP, Peters JM, Thomas SN, et al. Method comparison of SARS-CoV-2 serology assays involving three commercially available platforms and a novel in-house developed enzyme-linked immunosorbent assay. Clin Biochem 2020;86:34-5.

16. Tré-Hardy M, Wilmet A, Beukinga I, Favresse J, Dogné JM, Douxfils J, et al. Analytical and clinical validation of an ELISA for specific SARSCoV-2 IgG, IgA, and IgM antibodies. J Med Virol 2021;93:803-11.

17. Liu X, Zheng X, Liu B, Wu M, Zhang Z, Zhang G, et al. Serum IgM against SARS-CoV-2 correlates with in-hospital mortality in severe/critical patients with COVID-19 in Wuhan, China. Aging (Albany NY) 
$2020 ; 12: 12432-40$

18. Long QX, Deng HJ, Chen J, Hu J, Liu BZ, Liao P, et al. Antibody responses to SARS-CoV-2 in COVID-19 patients: the perspective application of serological tests in clinical practice. medRxiv 2020 (Updated on Mar 2020).
19. Vashist SK. In vitro diagnostic assays for COVID-19: recent advances and emerging trends. Diagnostics (Basel) 2020;10:202

20. Tuaillon E, Bolloré K, Pisoni A, Debiesse S, Renault C, Marie S, et al. Detection of SARS-CoV-2 antibodies using commercial assays and seroconversion patterns in hospitalized patients. J Infect 2020;81:e39-45. 